\title{
Consumers Attraction to Purchase Online: Website Quality as a Major Influencing Factor
}

\author{
Randy Kwaku Amponsah1, Samuel Antwi² \\ ${ }^{1}$ School of Economics and Management, Yangtze University, Jingzhou, China \\ ${ }^{2}$ School of Management and E-Business, Zhejiang Gongshang University, Hangzhou, China \\ Email:ramponsah17@gmail.com,samantwi88@outlook.com
}

How to cite this paper: Amponsah, R. K., \& Antwi, S. (2021). Consumers Attraction to Purchase Online: Website Quality as a Major Influencing Factor. Open Journal of Business and Management, 9, 1133-1150. https://doi.org/10.4236/ojbm.2021.93061

Received: March 11, 2021

Accepted: May 14, 2021

Published: May 17, 2021

Copyright (c) 2021 by author(s) and Scientific Research Publishing Inc. This work is licensed under the Creative Commons Attribution International License (CC BY 4.0).

http://creativecommons.org/licenses/by/4.0/

\begin{abstract}
Following the technological advancement from the days where the internet was not a commerce friendly space to now when it is a known secret that the internet is by far one of the greatest platforms for commercial activities, electronic commerce (e-commerce) has gained feet and become one of the easiest and convenient ways to reach out to a relatively larger geographical market for buying and selling of goods and services. Not only has this phenomenon made convenience a good part of commercial activities but also opened up the market to diversified goods and services and individuals or companies to select from, therefore making it highly imperative that these phenomena are looked into. Therefore, this research seeks to discuss how certain traits like the consumers' perception serve as a moderating tool in the online market space and consequently influence consumer purchase intentions.
\end{abstract}

\section{Keywords}

Information Quality, System Quality, Service Quality, Online Shopping Behavior, Commitment, Ghana

\section{Introduction}

The world has experienced a phenomenal technological transformation after the ban on using the internet for commercial activities was lifted in the early 1990s. This significant move made e-commerce possible, although certain activities in the prior years could be regarded as e-commerce. E-commerce has grown significantly over the past years because it has a larger geographical market than the traditional market. An e-commerce business does not require a consumer to be present at their premises before purchasing a product as buying a product is mainly online or on their website (Ahn et al., 2007; DeLone \& McLean, 2004). 
The introduction of the internet has made it possible for business owners to create a website that enables consumers to search for products and place an order online. And with functions like escrow payment system, addition of new payment method, on-site verification of e-retailers, designing the website in multiple languages, viewing products in multiple currencies, and many more, E-commerce companies such as Amazon, Alibaba, Walmart, Wish, and others over the past years have added more functions to their websites and have also improved their website and its interface to enhance a better shopping experience, thus, suggesting that Ghanaian online consumers shop in an online shopping platform with good website quality.

Consequently, Chen and Cheng (2009) and Bai et al. (2008) affirmed that an e-commerce website quality tends to improve an online consumer purchase intention. When an online consumer purchases a product online, the online shop ships the products to their delivery address provided. These days, customers can also interact with an online shop on the shopping website because of its improvement. On top of this, most e-commerce websites such as Alibaba and Amazon also provide tracking information of an order in a website without necessarily visiting a shipping and logistics company website to track the order, mostly in the case of third-party logistics. An e-commerce business's success to some extent depends on its capability to maintain their existing customers whilst ensuring that they can attract a new customer. One way to achieve this is to have a good and a functionable website. This is because, Ghanaians generally perceive electronic technological for business transactions to be very risky (Awiagah et al., 2016) because of poor website infrastructure (Mintah, 2018). Hence, to retain and attract new customers to an online shopping platform, e-commerce businesses need to have significant insight into what online consumers expect for a website's quality (Van Riel et al., 2004). To Hsu et al. (2014), some shopping websites retain and attract more online consumers than other shopping websites because they have an outstanding design and are easy to navigate. Also, Shin et al. (2013) opined that a key success for an e-commerce business is to have a good website.

Many researchers and scholars, including (Gao \& Li, 2019; Hsieh \& Tsao, 2014; Pandey \& Chawla, 2016; Shin et al., 2013; Wright et al., 2019), have conducted a lot of studies on the influence of website quality constructs on online shopping worldwide. However, to the best of our knowledge, it appears that no or limited studies have been conducted in Ghana on the subject matter. Consequently, this research sought to examine how website quality constructs influence online shopping among Ghanaian consumers while moderated by commitment.

The remainder of the research is as follows. The next section presents the theoretical background and hypothesis development based on the literature reviewed. This will be followed by the research methods and then continued with the data analysis. The next section will discuss our input and contributions to 
the study both research and practice. The last section will present the limitations and future research.

\section{Theoretical Background}

\subsection{Website Quality}

In e-commerce, a website serves as a place where a seller and an online consumer meet to transact. In this regard, online shopping's effectiveness and success depend on a website or the online shopping platform. Consequently, Aladwani and Palvia (2002) see website quality as assessing a website system's general performance. According to the researchers, such quality is subjective, and a high website rating indicates that a website's features meet a user's need. Chang and Chen (2008) measure a website user assessment of a website. A website user will conclude as to whether a website meets their needs based on the evaluation.

Previous studies reveal that website quality is a multi-dimensional construct with several dimensions (Aladwani \& Palvia, 2002; Delone \& McLean, 1992; DeLone \& McLean, 2003, 2004; Hoffman \& Novak, 2009; Loiacono et al., 2002; Urban et al., 2009; Wolfinbarger \& Gilly, 2003). However, it has been widely recognized that website quality comprises three constructs; information quality, system quality, and service quality (Delone \& McLean, 1992; DeLone \& McLean, 2003, 2004). Consequently, the study employs these three as website quality constructs.

In an e-commerce website, information is the content that explains a product offering. According to Hsieh and Tsao (2014), such content should be relevant, complete, personalized, and easily understandable by an online consumer. Therefore, DeLone and McLean (2003) opined that information quality means the quality of a website's content. A higher information quality speeds up an online consumer purchasing decision. Hence, an e-commerce website with a higher information quality is likely to generate more traffic from online consumers, subsequently leading to the actual purchase, than other e-commerce websites with low information quality (Tsao et al., 2016).

An e-commerce website's system quality is the general performance of a website system perceived by online consumers (Chen et al., 2015, 2017). According to DeLone and McLean (2004), system quality includes vital features such as availability, system usefulness, suitability, reliability, and response time. Online shopping is generally portrayed to be more convenient than traditional shopping. Therefore, an effective system quality would provide an online consumer a pleasant shopping experience, influencing their shopping behaviors (Tsao et al., 2016).

Regardless of the information provided by an online retailer in their online store, an online consumer may seek additional information before arriving at a final purchasing decision. Service quality comprises all phases of online consumer interaction with an e-commerce website (Parasuraman et al., 2005). E-commerce website service quality focuses on helping an online consumer effective and efficient online transaction. DeLone and McLean (2003) opined that 
it involves assurances, responsiveness, and reliability on the online retailer.

\subsection{Online Shopping Behavior}

E-commerce or online shopping takes place online. Bhattacharya and Mishra (2015) asserted that online shopping behavior comprises all behaviors relating to e-commerce. It includes visiting e-commerce or online shopping platform, searching for product information, ordering a product, enquiring more information from an online seller about a product, delivery schedules, and so forth (de Kerviler et al., 2016; Paluch \& Wunderlich, 2016). Online shopping in advanced countries is high and has been generally accepted by the public but is relatively low in developing countries because of infrastructural challenges and some negative perceptions associated with buying online. According to Bhattacharya Mishra (2015), such negative perception is mainly the fear of shopping online. Consequently, Ghanaian consumers prefer the traditional shopping method (Domeher et al., 2014) and are likely to rely on early online consumers to purchase a product online.

\subsection{Commitment}

Commitment is rooted in relationship marketing, and it helps an online retailer and online consumer establish a long-term business relationship (Garbarino \& Johnson, 1999). It is used to distinguish successful relationships from unsuccessful relationships (Roberts et al., 2003). Commitment has been defined by Ogba and Tan (2009) as an emotional feeling as a willingness to maintain a relationship with a retailer or brand. The researchers further added that commitment goes beyond a mere repurchase from the same retailer or brand. The definition implies for there to be a commitment between an online retailer and an online consumer, and both parties must be willing to make some sacrifices to maintain a long-standing relationship. In past literature, commitment has been found to have a significant positive relationship with behavioral intention (Fullerton, 2014; Moreira \& Silva, 2015; Shukla et al., 2016).

\section{Model Constructs and Hypothesis Development}

Figure 1 presents the proposed model of the study. The model intends to explain Ghanaians online shopping behavior in e-commerce. Website quality construct is considered the primary predictor of online shopping among Ghanaians with three constructs; information quality, system quality, and service quality. The model also proposes that commitment will mediate website quality construct and online shopping behavior.

\subsection{Information Quality and Its Effects on Online Shopping Behavior}

An e-commerce website's core is to provide accurate information on varieties of 


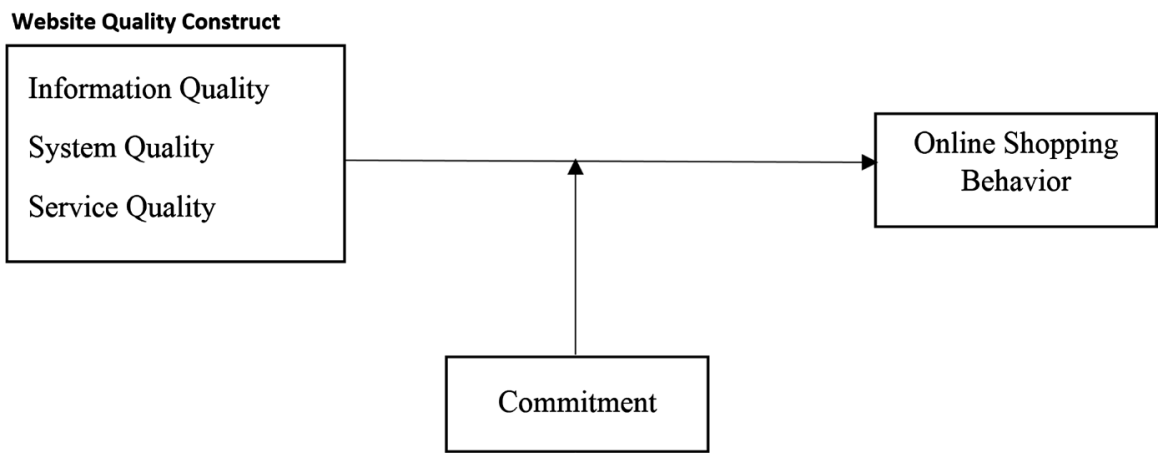

Figure 1. Concept model.

product offerings to online consumers. Thus, online consumers are much more interested in online retailers' product content as it helps them differentiate online retailers of high-quality products from those of low-quality products. Empirical evidence reveals that an e-commerce website's information quality positively influences online consumer shopping behavior. In their studies, Kim and Lim (2001) and Palmer (2006) found that information quality helped attain website success and consumer satisfaction. Lin and $\mathrm{Lu}$ (2000) also found information quality a relevant factor that affects online shopping behavior. Lin and $\mathrm{Lu}$ (2000) findings conform with Kuan et al. (2008), who found out that information quality is positively related to an online consumer purchase intention in their research. Hence, it is hypothesized that;

H1: There is a significant positive relationship between information quality and online shopping behavior among consumers in Ghana.

\subsection{System Quality and Its Effects on Online Shopping Behavior}

An e-commerce website service quality plays a vital role for an online retailer to arrive at a final purchasing decision. In an e-commerce website, a system quality denotes the efficient use of technology to ensure that an online consumer's personal and sensitive information is secured while providing an easy navigation platform. In support of this, Shneiderman and Plaisant (2010) claimed that online consumers do not prefer to shop in an e-commerce platform with an unsecured payment system. Again, Schonberg et al. (2000) and Yoo and Kim (2000) opined that e-commerce platforms should ensure that their website is easy to use and navigate by online consumers. Palmer (2006) found out that an online consumer will be attracted to an e-commerce platform if the website is easy to navigate. According to Ajay and Potti Srinivasa (2017), the information quality is not enough for an online consumer to rely on and arrive at a final purchasing decision as they are much more concerned with the system quality. Again, Kuan et al. (2008) found out that system quality is positively related to an online consumer's decision to purchase from a website. Therefore, it is hypothesized that;

H2: There is a significant positive relationship between system quality and online shopping behavior among the consumers in Ghana. 


\subsection{Service Quality and Its Effects on Online Shopping Behavior}

Sometimes, a product description may not be enough for an online consumer to arrive at a purchasing decision. Consequently, they may seek additional information or clarification from an online retailer. Because e-commerce does not involve face-to-face interaction between the transacting parties, online retailers need to have reliable customer service to attend to their customers' needs and concerns. Besides, the website must be reliable, thus, honoring all their promises. Literature available indicates that service quality influences an online consumer's decision to purchase from an e-commerce platform. To Ajay and Potti Srinivasa (2017), service quality helps attain customer satisfaction, which eventually will lead to a purchase intention. At the same time, Sun et al. (2015) found out in their study that service quality affects online consumer purchase intention. Similarly, Kuan et al. (2008) found out that service quality affects online consumer purchasing intention. Thus:

H3: There is a significant positive relationship between service quality and online shopping behavior among the consumers in Ghana.

\subsection{Moderation Role of Commitment}

Commitment is vital when it comes to relationship building between an online seller and an online consumer. Commitment, in the long run, helps make an online consumer loyal to an online retailer. Previous research conducted by Lokhorst et al. (2013) had found commitment to influence behavior. Previous literature has paid less attention to the moderation effect of commitment on website quality constructs and online shopping behavior intention and behavior. The moderation effect of commitment is found in the relationship between consumer purchase intention and internet shopping behavior (Rehman et al., 2019). Drawing on this previous literature, we expect a moderating effect of commitment on website quality constructs and online shopping behavior. Hence, we prose the hypothesis:

H4: Commitment significantly and positively moderates the relationship between website quality constructs and online shopping behavior among the consumers in Ghana.

\section{Research Methods}

\subsection{Measurement Development}

The study's conceptual framework was made up of three main constructs: website quality, commitment, and online shopping behavior. These constructs have been established in past studies. To compile a research instrument to test the research hypothesis, the researcher drew the past studies' measurement items and was modified to suit the context of the study. The items in the questionnaire were originally derived from (Jayawardhena, 2004; Lee et al., 2006; Mintah, 2018; Mukherjee \& Nath, 2007; Wixom \& Todd, 2005). 
A closed-ended questionnaire was developed to collect data from the participants. The questionnaire was made up of two parts. The first part focused on the demographic information of the participants. The participants were asked about their gender, age, online shopping experience, occupation, and educational level. The second part addressed the hypothesis posed on a seven-point Likert scale, with one (1) representing strongly disagree to seven (7) strongly agree. The independent variable, website quality, had three dimensions: information quality, system quality, and service quality. The information is the quality of the information on the online shopping platform, and it was measured using four items. The system quality, which focuses on the website's performance in terms of usage, was also measured using four items.

Similarly, the service quality and the moderator, commitment, were also measured using four items. The online shopping behavior was measured using five measurement items. To ensure that the questionnaire was devoid of any form of error and ambiguity, a preliminary version of the questionnaire was reviewed by four Doctoral students namely; Evans Mensah (Agricultural Economics and Management), Isaac Nunoo (Agribusiness), Joseph Asante Darkwah (Finance) and Moses Agyemang Ameyaw (Business Administration).

\subsection{Data Collection}

The data collection was carried out in Ghana. The study sample was Ghanaians in Ghana who purchase items from an e-commerce platform(s). The e-commerce platforms for this research were both the local platforms and the cross-border e-commerce platforms. To better target the study's desired participants, the researcher employed a web-based survey method as the means for data collection. The online version of the instruments was set-up on Microsoft Forms. A convenience sampling technique was used to select the participant from Accra Metropolis, the capital of Ghana. A message containing the purpose of the study and the Uniform Resource Locator (URL) was sent to the participant via WhatsApp Messenger. The participants participated in the studies voluntarily. Three hundred and seventy-two (372) responses were received within the specified period (December 14, 2020, to January 13, 2021) for data collection. The sample size was appropriate for the research given the sampling technique employed, the emerging e-commerce market in Ghana and the one-month period for the data collection.

\section{Data Analysis}

The researcher then employed a two-stage analytical procedure to analyzed the data obtained. Partial Least Square (PLS, SmartPLS Version 3.2.9) was used to assess the measurement model's reliability and validity. Also, Statistical Package for Social Sciences (SPSS) version 26 was used to analyze the participants' demographic data. 


\subsection{Respondents Demographic Information}

Table 1 shows that among the sample pool of 372, most of them were male $(54.3 \%)$, and the remaining were female $(45.7 \%)$. In terms of age, the majority $(40.3 \%)$ were from the age group of $20-25$, followed by $26-30(37.4 \%)$, above 30 years $(18.8 \%)$, and below 20 years (3.5\%). On online shopping experience, most of the respondents (34.9\%) had 1 - 3 years of experience, followed by 4-6 years (30.4\%) of experience, and then $7-10$ years (14\%) of experience, less than a year (11.3\%) experience, and lastly, above 10 years (9.4\%). With regards to occupation, most of the respondents (32.5\%) were in the private sector. This was followed by students $(24.2 \%)$ and then to the public sector $(19.6 \%)$, self-employed (18.3\%), and unemployed (5.4\%). In terms of the level of education, the results from the table indicate that more than half of the respondents had a degree (56.5\%), followed by Diploma (16.1\%), and then Masters (15.3), Senior High School (7\%) and lastly Ph.D. (5.1\%).

Table 1. Descriptive measurement of demographic variables $(N=372)$.

\begin{tabular}{|c|c|c|c|}
\hline Variables & Items & Frequency & $\%$ \\
\hline \multirow[t]{2}{*}{ Gender } & Male & 202 & 54.30 \\
\hline & Female & 170 & 45.70 \\
\hline \multirow[t]{4}{*}{ Age } & Below 20 & 13 & 3.50 \\
\hline & $20-25$ & 150 & 40.30 \\
\hline & $26-30$ & 139 & 37.40 \\
\hline & Above 30 & 70 & 18.80 \\
\hline \multirow[t]{5}{*}{ Online Shopping Experience (years) } & Below 1 & 42 & 11.3 \\
\hline & $1-3$ & 130 & 34.90 \\
\hline & $4-6$ & 113 & 30.40 \\
\hline & $7-10$ & 52 & 14.00 \\
\hline & Above 10 & 35 & 9.40 \\
\hline \multirow[t]{5}{*}{ Occupation } & Student & 90 & 24.20 \\
\hline & Public Sector & 73 & 19.60 \\
\hline & Private Sector & 121 & 32.50 \\
\hline & Self-employed & 68 & 18.30 \\
\hline & Unemployed & 20 & 5.40 \\
\hline \multirow[t]{5}{*}{ Level of Education } & Senior High School & 26 & 7.00 \\
\hline & Diploma & 60 & 16.10 \\
\hline & Degree & 210 & 56.50 \\
\hline & Masters & 57 & 15.30 \\
\hline & $\mathrm{PhD}$ & 19 & 5.10 \\
\hline
\end{tabular}

Note: $\mathrm{N}=$ Sample size and $\%=$ Percentage. 


\subsection{Measurement Model}

The researcher examined all the composite reliability scores and the indicator's outer loading to assess the reliability (internal consistency reliability and indicator reliability) of the measurement model (Fornell \& Larcker, 1981; Nunnally, 1978). All the composite reliability figures in Table 2 were above the cutoff value of 0.70. Again, all the Cronbach alpha of the constructs exceeds the standard of 0.7 , signifying a strong internal consistency. We also assessed the convergent validity and discriminant validity. According to $\mathrm{Hu}$ et al. (2004), the convergent

Table 2. Reliability and variability constructs (confirmatory factor analysis).

\begin{tabular}{|c|c|c|c|c|}
\hline Latent Variables & Loadings & CR & AVE & $a$ \\
\hline \multicolumn{5}{|l|}{ Information Quality } \\
\hline IQ1 & 0.898 & & & \\
\hline IQ2 & 0.842 & & & \\
\hline IQ3 & 0.884 & 0.929 & 0.767 & 0.899 \\
\hline IQ4 & 0.878 & & & \\
\hline \multicolumn{5}{|l|}{ System quality } \\
\hline SQ1 & 0.846 & & & \\
\hline SQ2 & 0.848 & & & \\
\hline SQ3 & 0.874 & 0.921 & 0.745 & 0.886 \\
\hline SQ4 & 0.883 & & & \\
\hline \multicolumn{5}{|l|}{ Service quality } \\
\hline SVQ1 & 0.840 & & & \\
\hline SVQ2 & 0.864 & & & \\
\hline SVQ3 & 0.864 & 0.920 & 0.741 & 0.884 \\
\hline SVQ4 & 0.875 & & & \\
\hline \multicolumn{5}{|l|}{ Commitment } \\
\hline $\mathrm{CO} 1$ & 0.862 & & & \\
\hline $\mathrm{CO} 2$ & 0.841 & & & \\
\hline $\mathrm{CO} 3$ & 0.870 & 0.921 & 0.746 & 0.886 \\
\hline $\mathrm{CO} 4$ & 0.882 & & & \\
\hline \multicolumn{5}{|c|}{ Online Shopping Behavior } \\
\hline OSB1 & 0.745 & & & \\
\hline OSB2 & 0.793 & & & \\
\hline OSB3 & 0.843 & 0.901 & 0.695 & 0.862 \\
\hline OSB4 & 0.835 & & & \\
\hline OSB5 & 0.795 & & & \\
\hline
\end{tabular}

Note: Sample size $(\mathrm{N})=372, \mathrm{CR}=$ Composite Reliability, AVE = Average Variance Extracted, $\alpha=$ Cronbach's Alpha, IQ = Information Quality, SQ = System Quality, SVQ = Service Quality, CO = Commitment, OSB $=$ Online Shopping Behavior. 
validity assessment builds on the average variance extracted (AVE) values. The researchers further said that the AVE should meet the benchmark value $(>0.50)$. The results from Table 2 indicate that the AVE of each construct is well above the benchmark of 0.50 , demonstrating high levels of convergent validity. Also, each indicator's loading on its respective factor exceeds 0.70 (see Table 2). The data's discriminant validity was assessed according to Fornell and Larcker (1981) procedure. Thus, the square root of AVEs of each construct should be larger than the values of the correlations between the construct and other constructs. Therefore, these test results in Table 3 show adequate discriminant validity.

\subsection{Structural Model}

The structural model was also assessed using the Partial Least Square (PLS, SmartPLS Version 3.2.9). The PLS approach was appropriate for the research because it is suitable for examining the casual relationship among latent constructs (Hair et al. 2011). The results are presented in Table 4 and Table 5 below. The path coefficients or the original sample of the constructs have a standardized value ranging from -1 and +1 . The closer the estimated path coefficients are geared towards 1 , the stronger the forecast relationship. Also, the closer the estimated coefficients to 0 , the weaker the relationship. Observations of the coefficient in Table 4 and Table 5 show a positive relationship among all the construct, except the mediating role of commitment between information quality and online shopping behavior and between system quality and online shopping

Table 3. Inter-correlation (discriminant validity test) for the latent variables.

\begin{tabular}{cccccc}
\hline Variables & IQ & SQ & SVQ & CO & OSB \\
\hline IQ & $\mathbf{0 . 8 7 6}$ & & & & \\
SQ & 0.807 & $\mathbf{0 . 8 6 3}$ & & & \\
SVQ & 0.736 & 0.816 & $\mathbf{0 . 8 6 1}$ & & \\
CO & 0.688 & 0.733 & 0.807 & $\mathbf{0 . 8 6 4}$ & \\
OSB & 0.668 & 0.697 & 0.760 & 0.825 & $\mathbf{0 . 8 3 4}$ \\
\hline
\end{tabular}

Note: Values in bold are square root of AVE, IQ = Information Quality, SQ = System Quality, SVQ = Service Quality, CO = Commitment, OSB = Online Shopping Behavior.

Table 4. Path coefficients of the structural model constructs.

\begin{tabular}{ccccccc}
\hline $\begin{array}{c}\text { Constructs } \\
\text { Effects }\end{array}$ & OS & SM & STDEV & $\begin{array}{c}\text { T-Value } \\
(\mid \text { O /STDEV } \mid)\end{array}$ & $P$-values & Decision \\
\hline IQ - OSB & 0.102 & 0.104 & 0.048 & 2.126 & $0.034^{\star *}$ & Accepted \\
SQ - OSB & 0.055 & 0.057 & 0.058 & 0.941 & 0.347 & Not Accepted \\
SVQ - OSB & 0.179 & 0.178 & 0.063 & 2.863 & $0.004^{\star * *}$ & Accepted \\
CO - OSB & 0.558 & 0.559 & 0.070 & 7.943 & $0.000^{\star * *}$ & Accepted \\
\hline
\end{tabular}

Note: ${ }^{* * *} p$-value $<0.01,{ }^{* *} p$-value $<0.05$, OS $=$ Original Sample, SM $=$ Sample Mean, STDEV $=$ Standard Deviation, IQ = Information Quality, SQ = System Quality, SVQ = Service Quality, CO = Commitment, OSB = Online Shopping Behavior. 
Table 5. Moderation analysis.

\begin{tabular}{ccccccc}
\hline Constructs Effects & OS & SM & STDEV & $\begin{array}{c}\text { T-Value } \\
(\mid \text { O/STDEV } \mid)\end{array}$ & $P$-values & Decision \\
\hline IQ - CO - OSB & -0.008 & -0.013 & 0.054 & 0.143 & 0.887 & Not Accepted \\
SQ - CO - OSB & 0.040 & 0.045 & 0.060 & 0.674 & 0.500 & Not Accepted \\
SVQ - CO - OSB & -0.038 & -0.035 & 0.048 & 0.798 & 0.425 & Not Accepted \\
\hline
\end{tabular}

Note: OS = Original Sample, SM = Sample Mean, STDEV = Standard Deviation, IQ = Information Quality, $\mathrm{SQ}=$ System Quality, $\mathrm{SVQ}=$ Service Quality, CO = Commitment, OSB = Online Shopping Behavior.

behavior, although there are variations in the magnitude of the effects.

The results from Table 4 indicate that three out of the four hypotheses tested were accepted. For example, the results revealed that information quality (IQ) significantly and positively influence online shopping behavior (OSB) as (OS = 0.102 , $\mathrm{t}$-value $=2.126, p$-value $<0.05)$. Again, service quality (SVQ) was found to have a significant and positive influence on online shopping behavior (OSB) as $(\mathrm{OS}=0.179, \mathrm{t}$-value $=2.863, p$-value $<0.01)$. Despite this, system quality (SQ) did not have a significant influence on online shopping behavior (OSB) as (OS = 0.055 , $\mathrm{t}$-value $=0.941, p$-value $>0.05)$. The results also found that commitment (CO) has a significant and positive influence on online shopping behavior (OSB) as $(\mathrm{OSB}=0.558, \mathrm{t}$-value $=7.943, p$-value $>0.05)$ although was not part of the research hypothesis for the study.

Table 5 presents the moderation effect of commitment between website quality constructs and online shopping behavior. The table results indicate that there were no moderation effects between commitment and the other constructs. Thus, commitment (CO) does not moderate the relationship between information quality (IQ) and online shopping behavior $(\mathrm{OSB})$ as $(\mathrm{OS}=-0.008$, $\mathrm{t}$-value $=$ $0.143, p$-value $>0.05)$. Also, commitment does not also moderate the relationship between system quality (SQ) and online shopping behavior (OSB) as (OS = 0.040 , t-value $=0.674, p$-value $>0.05)$. Lastly, commitment does not moderate the relationship between service quality (SVQ) and online shopping behavior $(\mathrm{OSB})$ as $(\mathrm{OS}=-0.038$, $\mathrm{t}$-value $=0.798, p$-value $>0.05)$.

\section{Discussion and Contributions}

\subsection{Discussion of Findings}

The study objective was to examine the influence of information quality (IQ), system quality (SQ), and service quality (SVQ) on online shopping behavior. Additionally, the study sought to find the moderating role of commitment (CO) between information quality (IQ), system quality (SQ), service quality (SVQ), and online shopping behavior (OSB) in the Ghanaian context.

Figure 2 is the Structural Model. Among the independent variables, information quality (IQ) was found to positively and significantly affect online shopping behavior (OSB). Thus, Ghanaian online consumers consider the information provided by online retailers on their product offerings on their website as beneficial 


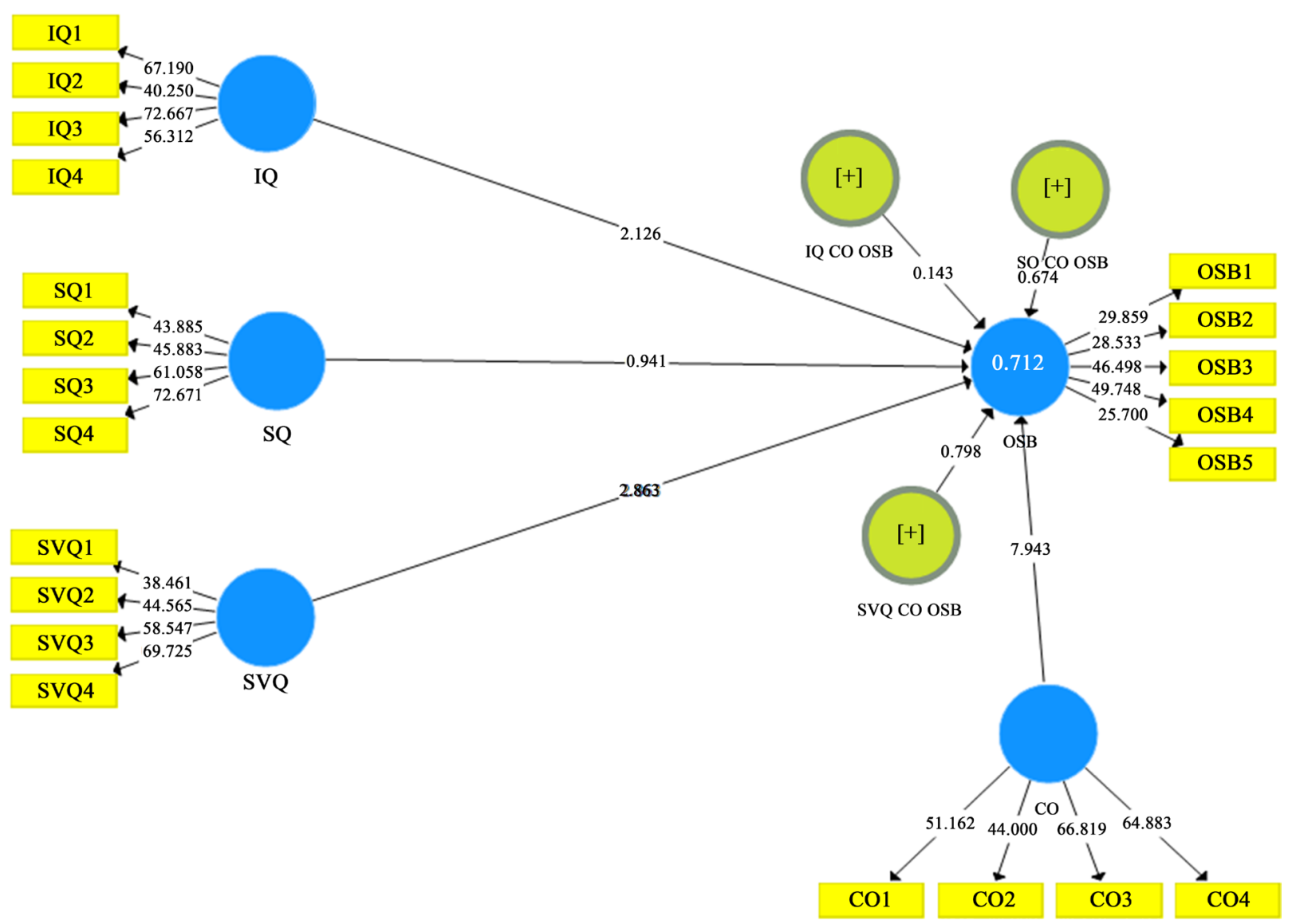

Figure 2. Structural model.

and helpful when considering purchasing online. It is therefore not surprising the Ghanaian online retailers will consider information provided on a website as a significant factor in their purchasing behavior because most Ghanaians prefer to buy from a traditional retailer (Domeher et al., 2014) where they can have the opportunity to examine the product before arriving at a purchasing decision physically. Consequently, the kind of information online retailers provides on their shopping platforms would influence their shopping behavior. Supporting past studies' findings include (Kim \& Lim, 2001; Kuan et al., 2008; Palmer, 2006).

Moreover, the study confirms a significant and positive relationship between system quality (SQ) and online shopping behavior (OSB). Thus, Ghanaian online consumers are concerned about personal and sensitive information such as their credit or debit card information, address information, and issues such as website interface and navigation. Generally, no consumer wants their payment information to be hacked and may be cautious when making an online payment. The finding of our work is in line with the outcome of Kuan et al. (2008); Palmer (2006) and Yoo and Kim (2000). It is reasonable that an e-commerce website's system quality influences Ghanaian online consumer shopping behavior as information quality may not be enough to influence their shopping behavior (Ajay 


\section{\& Potti Srinivasa, 2017).}

Similarly, service quality (SVQ) had a significant positive effect on online shopping behavior (OSB). The finding implies that Ghanaian online consumers consider the kind of services that e-commerce platform provides to them when shopping on their website or platform. Such service includes timely response to their inquiries and concerns and so forth. This finding is supported by Ajay and Potti Srinivasa (2017) and Sun et al. (2015), who in their studies found a significantly positive relationship between service quality and online consumer intention to purchase. The present research also detects a positive and significant effect of commitment (CO) and online shopping behavior (OSB). Commitment is seen as one of the foundations in relationship marketing, and it is essential for shaping online consumer loyalty to an e-retailer or a shopping platform. The finding confirms earlier findings of Fullerton (2014) and Shukla et al. (2016), who found commitment to have a significant positive effect on behavioral intention.

Nonetheless, commitment does not moderate the relationship between the website quality constructs (information quality, system quality, and service quality) and online shopping behavior. Thus, commitment does not alter the strength of the relationship between website quality constructs and online shopping behavior among Ghanaian online consumers, although commitment has a significant positive effect on online shopping behavior. The finding contradicts Rehman et al. (2019), who found a moderation effect of commitment between consumer purchase intention and internet shopping behavior among online consumers.

\subsection{Contributions to Research}

The results of this study provide some research contributions. First of all, the study contributes to the limited studies that have been conducted in Ghana. Although website quality constructs on online shopping have been widely investigated (Ajay \& Potti Srinivasa, 2017; Wang et al., 2015; Zhou et al., 2009), not many studies on these variables have been conducted in Ghana. It is essential to note that consumer characteristics differ from country to country because of different cultural and technological backgrounds. The advancement of technology in the developed countries such as China, the United States of America, and the European countries may ease some of the challenges associated with buying a product from an e-commerce site. In general, the study's findings imply that online retailers or e-commerce platforms who would like to induce Ghanaian online consumers' willingness to buy from their platform ought to provide accurate or quality information, a good website system, and service quality. Finally, the study extends the research about website quality in e-commerce by investigating the moderation role of commitment. To the best of our knowledge and literature, not much work has been done on website quality and online shopping using a moderator's commitment. As such, this research would offer additional 
insights into the salience of website quality in the context of online shopping.

\subsection{Contribution to Practice}

The study also provides several contributions that e-commerce platforms and online retailers may consider relevant in online shopping. First, the study's findings suggest that information quality can increase Ghanaian online consumers' shopping behavior. This indicates that, for e-commerce platforms or online retailers to maximize Ghanaian online consumers' shopping behavior, they must improve the information they provide on their website and/or products. Quality product information can help minimize some doubts that online consumers may have. Also, system quality exhibits a significant positive influence on Ghanaian online consumers' shopping behavior. E-commerce platforms need to provide a well-designed website that is easy to use and navigate and ensure that buyers' personal or private information will not be leaked or hacked. There is also the need for e-commerce platforms to occasionally seek suggestions from their buyers on some of the functions needed to be added to their website to enhance customer satisfaction. At the same time, service quality tends to increase the online shopping behavior of Ghanaian online retailers. The finding implies that not all aspects of online shopping behavior can influence information quality and system quality. E-commerce platforms need to pay closer attention to their customer concerns as the cost of switching to a different platform or an online retailer may be zero. Finally, a commitment was found to have the capacity to influence online shopping behavior but has no moderation effect on website quality constructs and online shopping behavior. Therefore, e-commerce platforms or online retailers need to build a stronger relationship with their customers because retaining an old consumer is easier than gaining new ones due to the market's competitive nature.

\section{Limitations and Future Research}

While the study aimed at investing the influence of website quality on online shopping behavior in the Ghanaian context, it has some limitations. First, several factors can influence Ghanaians, online consumers, in an online shopping platform, but this study concentrated on only website quality constructs. Future research should investigate other factors that can influence online shopping behavior among online consumers in Ghana. A second limitation is that the study focuses on online shopping behavior in Ghana. Future research should focus on testing the results in other emerging markets in Africa, as most studies have been conducted in advanced countries. Again, the research did not investigate the post review or reactions of Ghanaian consumers who shops on an e-commerce platform. The study recommends that future studies research Ghanaian online consumers' reactions to shopping on an e-commerce site over time. Thus, a longitudinal study should be conducted to help extend understanding of 
the causal relationships between website quality constructs and online shopping behavior, with commitment serving as a moderator.

\section{Conflicts of Interest}

The authors declare no conflicts of interest regarding the publication of this paper.

\section{References}

Ahn, T., Ryu, S., \& Han, I. (2007). The Impact of Web Quality and Playfulness on User Acceptance of Online retailIng. Information and Management, 44, 263-275. https://doi.org/10.1016/j.im.2006.12.008

Ajay, K, N., \& Potti Srinivasa, R. (2017). Effect of Website Quality on Customer Satisfaction and Purchase Intention in Online Travel Ticket Booking Websites. Management, $7,168-173$.

Aladwani, A. M., \& Palvia, P. C. (2002). Developing and Validating an Instrument for Measuring User-Perceived Web Quality. Information and Management, 39, 467-476. https://doi.org/10.1016/S0378-7206(01)00113-6

Awiagah, R., Kang, J., \& Lim, J. I. (2016). Factors Affecting E-Commerce Adoption among SMEs in Ghana. Information Development, 32, 815-836. https://doi.org/10.1177/0266666915571427

Bai, B., Law, R., \& Wen, I. (2008). The Impact of Website Quality on Customer Satisfaction and Purchase Intentions: Evidence from Chinese Online Visitors. International Journal of Hospitality Management, 27, 391-402. https://doi.org/10.1016/j.ijhm.2007.10.008

Bhattacharya, S., \& Mishra, B. B. (2015). Evolution, Growth and Challenges in E-Commerce Industry: A Case of India. Sumedha Journal of Management, 4, 45-58. https://search.proquest.com/openview/1b76dbc74b143036cf037c7a19374429/1?pq-orig $\underline{\text { site }}=$ gscholar $\& \mathrm{cbl}=1936345$

Chang, H. H., \& Chen, S. W. (2008). The Impact of Online Store Environment cues on Purchase Intention: Trust and Perceived Risk as a Mediator. Online Information Review, 32, 818-841. https://doi.org/10.1108/14684520810923953

Chen, C. W. D., \& Cheng, C. Y. J. (2009). Understanding Consumer Intention in Online Shopping: A Respecification and Validation of the DeLone and McLean Model. Behaviour and Information Technology, 28, 335-345. https://doi.org/10.1080/01449290701850111

Chen, X., Huang, Q., \& Davison, R. M. (2017). The Role of Website Quality and Social Capital in Building Buyers' Loyalty. International Journal of Information Management, 37, 1563-1574. https://doi.org/10.1016/j.ijinfomgt.2016.07.005

Chen, X., Huang, Q., Davison, R. M., \& Hua, Z. (2015). What Drives Trust Transfer? The Moderating Roles of Seller-Specific and General Institutional Mechanisms. International Journal of Electronic Commerce, 20, 261-289. https://doi.org/10.1080/10864415.2016.1087828

de Kerviler, G., Demoulin, N. T. M., \& Zidda, P. (2016). Adoption of In-Store Mobile Payment: Are Perceived Risk and Convenience the Only Drivers? Journal of Retailing and Consumer Services, 31, 334-344. https://doi.org/10.1016/j.jretconser.2016.04.011

Delone, W. H., \& McLean, E. R. (1992). The Quest for the Dependent Variable. Information System Research, 3, 60-95. https://doi.org/10.1287/isre.3.1.60

DeLone, W. H., \& McLean, E. R. (2003). The DeLone and McLean Model of Information 
Systems Success: A Ten-Year Update. Journal of Management Information Systems, 19, 9-30. https://doi.org/10.1080/07421222.2003.11045748

DeLone, W. H., \& McLean, E. R. (2004). Measuring E-Commerce Success: Applying the DeLone and McLean Information Systems Success Model. International Journal of Electronic Commerce, 9, 31-47. https://doi.org/10.1080/10864415.2004.11044317

Domeher, D., Frimpong, J., \& Appiah, T. (2014). Adoption of Financial Innovation in the Ghanaian Banking Industry. African Review of Economics and Finance, 6, 88-114. https://www.ajol.info/index.php/aref/article/view/113460

Fornell, C., \& Larcker, D. F. (1981). Evaluating Structural Equation Models with Unobservable Variables and Measurement Error. Journal of Marketing Research, 18, 39-50. https://doi.org/10.1177/002224378101800104

Fullerton, G. (2014). The Moderating Effect of Normative Commitment on the Service Quality-Customer Retention Relationship. European Journal of Marketing, 48, 657-673. https://doi.org/10.1108/EJM-06-2011-0333

Gao, W., \& Li, X. (2019). Building Presence in an Online Shopping Website: The Role of Website Quality. Behaviour and Information Technology, 38, 28-41. https://doi.org/10.1080/0144929X.2018.1509127

Garbarino, E., \& Johnson, M. S. (1999). The Different Roles of Satisfaction, Trust, and Commitment in Customer Relationships. Journal of Marketing, 63, 70-87. https://doi.org/10.1177/002224299906300205

Hair, J. F., Ringle, C. M., \& Sarstedt, M. (2011). PLS-SEM: Indeed a Silver Bullet. Journal of Marketing Theory and Practice, 19, 139-152. https://doi.org/10.2753/MTP1069-6679190202

Hoffman, D. L., \& Novak, T. P. (2009). Flow Online: Lessons Learned and Future Prospects. Journal of Interactive Marketing, 23, 23-34. https://doi.org/10.1016/j.intmar.2008.10.003

Hsieh, M. T., \& Tsao, W. C. (2014). Reducing Perceived Online Shopping Risk to Enhance Loyalty: A Website Quality Perspective. Journal of Risk Research, 17, 241-261. https://doi.org/10.1080/13669877.2013.794152

Hsu, M. H., Chang, C. M., Chu, K. K., \& Lee, Y. J. (2014). Determinants of Repurchase Intention in Online Group-Buying: The Perspectives of DeLone \& McLean Is Success Model and Trust. Computers in Human Behavior, 36, 234-245. https://doi.org/10.1016/j.chb.2014.03.065

Hu, X., Lin, Z., Whinston, A. B., \& Zhang, H. (2004). Hope or Hype: On the Viability of Escrow Services as Trusted Third Parties in Online Auction Environments. Information Systems Research, 15, 236-249. https://doi.org/10.1287/isre.1040.0027

Jayawardhena, C. (2004). Measurement of Service Quality in Internet Banking: The Development of an Instrument. Journal of Marketing Management, 20, 185-207. https://doi.org/10.1362/026725704773041177

Kim, S. Y., \& Lim, Y. J. (2001). Consumers' Perceived Importance of and Satisfaction with Internet Shopping. Electronic Markets, 11, 148-154.

Kuan, H. H., Bock, G. W., \& Vathanophas, V. (2008). Comparing the Effects of Website Quality on Customer Initial Purchase and Continued Purchase at E-Commerce Websites. Behaviour and Information Technology, 27, 3-16. https://doi.org/10.1080/01449290600801959

Lee, J. R., Yoo, D. K., \& Lee, Y. K. (2006). Effects of Relational Efforts on Behavioral Intentions in Internet Book Site: The Mediating Roles of Relationship Quality. Daehan 
Journal of Business, 19, 1843-1866.

Lin, J. C. C., \& Lu, H. (2000). Towards an Understanding of the Behavioural Intention to Use a Web Site. International Journal of Information Management, 20, 197-208. https://doi.org/10.1016/S0268-4012(00)00005-0

Loiacono, E. T., Watson, R. T., \& Goodhue, D. L. (2002). WebQual ${ }^{\mathrm{TM}}$ : A Measure of Web Site Quality. American Marketing Association Winter Educators' Conference, Austin, $1-71$.

https://slidelegend.com/webquala-a-measure-of-web-site-quality-citeseerx 59e1579017 23dd97c3967c9b.html

Lokhorst, A. M., Werner, C., Staats, H., van Dijk, E., \& Gale, J. L. (2013). Commitment and Behavior Change: A Meta-Analysis and Critical Review of Commitment-Making Strategies in Environmental Research. Environment and Behavior, 45, 3-34.

https://doi.org/10.1177/0013916511411477

Mintah, S. C. (2018). Consumer Perceived Risk and Online Shopping in Ghana: The Moderating Role of Electronic-Word of Mouth. Master's Thesis, Accra: University of Ghana. http://ugspace.ug.edu.gh/bitstream/handle/123456789/31162

Moreira, A. C., \& Silva, P. M. (2015). The trust-Commitment Challenge in Service Quality-Loyalty Relationships. International Journal of Health Care Quality Assurance, 28, 253-266. https://doi.org/10.1108/IJHCQA-02-2014-0017

Mukherjee, A., \& Nath, P. (2007). Role of Electronic Trust in Online Retailing: A Re-Examination of the Commitment-Trust Theory. European Journal of Marketing, 41, 1173-1202. https://doi.org/10.1108/03090560710773390

Nunnally, J. C. (1978). Psychometric Theory. New York, NY: McGraw-Hill. https://www.worldcat.org/title/psychometric-theory/oclc/3167590

Ogba, I., \& Tan, Z. (2009). Exploring the Impact of Brand Image on Customer Loyalty and Commitment in China. Journal of Technology Management in China, 4, 132-144. https://doi.org/10.1108/17468770910964993

Palmer, J. W. (2006). Web Site Usability, Design, and Performance Metrics. Information Systems Research, 12, 151-167. https://doi.org/10.1287/isre.13.2.151.88

Paluch, S., \& Wunderlich, N. V. (2016). Contrasting Risk Perceptions of Technology-Based Service Innovations in Inter-Organizational Settings. Journal of Business Research, 69, 2424-2431. https://doi.org/10.1016/j.jbusres.2016.01.012

Pandey, S., \& Chawla, D. (2016). Understanding Indian Online Clothing Shopper Loyalty and Disloyalty: The Impact of E-Lifestyles and Website Quality. Journal of Internet Commerce, 15, 332-352. https://doi.org/10.1080/15332861.2016.1237238

Parasuraman, A., Zeithaml, V. A., \& Malhotra, A. (2005). E-S-QUAL: A Multiple-Item Scale for Assessing Electronic Service Quality. Journal of Service Research, 7, 213-233. https://doi.org/10.1177/1094670504271156

Rehman, S. U., Bhatti, A., Mohamed, R., \& Ayoup, H. (2019). The Moderating Role of Trust and Commitment between Consumer Purchase Intention and Online Shopping Behavior in the Context of Pakistan. Journal of Global Entrepreneurship Research, 9, Article No. 43. https://doi.org/10.1186/s40497-019-0166-2

Roberts, K., Varki, S., \& Brodie, R. (2003). Measuring the Quality of Relationships in Consumer Services: An Empirical Study. European Journal of Marketing, 37, 169-196. https://doi.org/10.1108/03090560310454037

Schonberg, E., Cofino, T., Hoch, R., Podlaseck, M., \& Spraragen, S. L. (2000). Measuring Success: E-Business Intelligence Is a Complex, Yet Vital, Element to Building a Strong 
Customer Base. Communications of the ACM, 43, 53-57.

https://doi.org/10.1145/345124.345142

Shin, J. I., Chung, K. H., Oh, J. S., \& Lee, C. W. (2013). The effect of Site Quality on Repurchase Intention in Internet Shopping through Mediating Variables: The Case of University Students in South Korea. International Journal of Information Management, 33, 453-463. https://doi.org/10.1016/j.ijinfomgt.2013.02.003

Shneiderman, B., Plaisant, C., Cohen, M. S., Jacobs, S., Elmqvist, N., \& Diakopoulos, N. (2010). Designing the User Interface: Strategies for Effective Human-Computer Interaction (6th ed.). Hoboken, NJ: Pearson. https://nsuworks.nova.edu/gscis facbooks/18/

Shukla, P., Banerjee, M., \& Singh, J. (2016). Customer Commitment to Luxury Brands: Antecedents and Consequences. Journal of Business Research, 69, 323-331. https://doi.org/10.1016/j.jbusres.2015.08.004

Sun, J., Wang, Y., Yang, Z., \& Zhang, Y. (2015). Rethinking E-Commerce Service Quality: Does Website Quality Still Suffice? Journal of Computer Information Systems, 55, 62-72. https://doi.org/10.1080/08874417.2015.11645788

Tsao, W. C., Hsieh, M. T., \& Lin, T. M. Y. (2016). Intensifying Online Loyalty! The Power of Website Quality and the Perceived Value of Consumer/Seller Relationship. Industrial Management and Data Systems, 116, 1987-2010. https://doi.org/10.1108/IMDS-07-2015-0293

Urban, G. L., Amyx, C., \& Lorenzon, A. (2009). Online Trust: State of the Art, New Frontiers, and Research Potential. Journal of Interactive Marketing, 23, 179-190. https://doi.org/10.1016/j.intmar.2009.03.001

Van Riel, A. C. R., Semeijn, J., \& Pauwels, P. (2004). Online Travel Service Quality: The Role of Pre-Transaction Services. Total Quality Management and Business Excellence, 15, 475-493. https://doi.org/10.1080/1478336042000183578

Wang, L., Law, R., Guillet, B. D., Hung, K., \& Fong, D. K. C. (2015). Impact of Hotel Website Quality on Online Booking Intentions: ETrust as a Mediator. International Journal of Hospitality Management, 47, 108-115.

https://doi.org/10.1016/j.ijhm.2015.03.012

Wixom, B. H., \& Todd, P. A. (2005). A Theoretical Integration of User Satisfaction and Technology Acceptance. Information Systems Research, 16, 85-102. https://doi.org/10.1287/isre.1050.0042

Wolfinbarger, M., \& Gilly, M. C. (2003). eTailQ: Dimensionalizing, Measuring and Predicting Etail Quality. Journal of Retailing, 79, 183-198. https://doi.org/10.1016/S0022-4359(03)00034-4

Wright, L. B., Haug, J. C., \& Huckabee, A. (2019). Blueprint for Retail Website Design: Attracting and Retaining Millennial Online Shoppers. Journal of Internet Commerce, 18, 170-196. https://doi.org/10.1080/15332861.2019.1584844

Yoo, B., \& Kim, J. (2000). Experiment on the Effectiveness of Link Structure for Convenient Cybershopping. Journal of Organizational Computing and Electronic Commerce, 10, 241-256. https://doi.org/10.1207/S15327744JOCE1004 03

Zhou, T., Lu, Y., \& Wang, B. (2009). The Relative Importance of Website Design Quality and Service Quality in Determining Consumers' Online Repurchase Behavior. Information Systems Management, 26, 327-337. https://doi.org/10.1080/10580530903245663 